\title{
PRINCIPAL COMPONENT ANALYSIS OF CHLOROPHYLL CONTENT IN TOBACCO, BEAN AND PETUNIA PLANTS EXPOSED TO DIFFERENT TROPOSPHERIC OZONE CONCENTRATIONS
}

\author{
Klaudia BOROWIAK ${ }^{11}$, Janina ZBIERSKA ${ }^{1}$, Anna BUDKA ${ }^{2}$, \\ Dariusz KAYZER ${ }^{2}$ \\ ${ }^{1}$ Poznań University of Life Sciences, \\ Department of Ecology and Environmental, Poznan, Poland \\ ${ }^{2}$ Poznań University of Life Sciences, \\ Department of Mathematical and Statistical Methods, Poznań, Poland
}

\begin{abstract}
Three plant species were assessed in this study - ozone-sensitive and -resistant tobacco, ozone-sensitive petunia and bean. Plants were exposed to ambient air conditions for several weeks in two sites differing in tropospheric ozone concentrations in the growing season of 2009. Every week chlorophyll contents were analysed. Cumulative ozone effects on the chlorophyll content in relation to other meteorological parameters were evaluated using principal component analysis, while the relation between certain days of measurements of the plants were analysed using multivariate analysis of variance. Results revealed variability between plant species response. However, some similarities were noted. Positive relations of all chlorophyll forms to cumulative ozone concentration (AOT 40) were found for all the plant species that were examined. The chlorophyll b/a ratio revealed an opposite position to ozone concentration only in the ozone-resistant tobacco cultivar. In all the plant species the highest average chlorophyll content was noted after the $7^{\text {th }}$ day of the experiment. Afterwards, the plants usually revealed various responses. Ozone-sensitive tobacco revealed decrease of chlorophyll content, and after few weeks of decline again an increase was observed. Probably, due to the accommodation for the stress factor. While during first three weeks relatively high levels

1 Corresponding author: Poznań University of Life Sciences, Department of Ecology and Environmental Protection, Piątkowska 94C, 60-649 Poznań, Poland;

e-mail: klaudine@up.poznan.pl, +48618466510
\end{abstract}


of chlorophyll contents were noted in ozone-resistant tobacco. Petunia revealed a slow decrease of chlorophyll content and the lowest values at the end of the experiment. A comparison between the plant species revealed the highest level of chlorophyll contents in ozone-resistant tobacco.

Keywords: tropospheric ozone, sensitive, resistant, chlorophyll, principal component analysis (PCA)

\section{INTRODUCTION}

Tropospheric ozone is one of the most important air pollutants. Its concentration has been increased during the last few decades and it an elevation of its concentrations in the next years is predicted [5]. Mainly because of the increasing number of cars, which are the main source of ozone precursors (such as nitrogen oxides, volatile organic compounds, carbon oxides). Tropospheric ozone is created during the summer season, when higher solar radiation occurs, and photochemical reactions occur [1]. Plants are the most endangered due to their permanent occurrence in outside conditions during the growing season. This is especially valid for crops. The first symptom of an ozone negative effect on plants is a decrease of photosynthesis efficiency. Imbalances in this phase lead to a decrease of absorber energy and the creation of reactive oxygen species in chloroplasts $[10,11]$. The photosynthesis process is conducted in chloroplasts and the occurrence of chlorophyll $a$ and $b$ is necessary for the proper functioning of $\mathrm{CO}_{2}$ assimilation. A decrease in $\mathrm{CO}_{2}$ assimilation can cause carbon allocation and a decrease of plant productivity [8]. Ozone can cause chlorophyll reduction in exposed leaves, and in turn a decrease of photosynthesis activity [13]. This was already confirmed in many plant species $[2,4]$. However, some species did not reveal a decrease of chlorophyll due to ozone exposure [15]. The chlorophyll content depends on the plant species and cultivar, as well as on the leaf physiological age.

There are many doubts about the effect of ozone on chlorophyll forms. For some species chlorophyll $a$ was found to be more sensitive, while for the other species chlorophyll $b$. The sensitivity of both forms is connected with plant species and cultivar. Plants exposed to ozone sometimes revealed an increase of the chlorophyll b/a ratio, which suggested higher chlorophyll reduction [13].

The tropospheric ozone effect on plants cumulates during the growing season. However, there is a limited number of investigations concerning this aspect of ozone influence. Usually, investigations were carried out for a short time period and after fumigation or exposure to ambient conditions. The aim of the 
presented study was to analyze cumulative ozone effect on the chlorophyll contents in three plant species during the growing season. As well as, comparison of plant species response. The data obtained were analysed and graphically presented using principal component analysis (PCA).

\section{MATERIALS AND METHODS}

\subsection{Experimental design}

Ozone-sensitive ('Bel W3') and -resistant ('Bel B') tobacco (Nicotiana tabacum L.), ozone-sensitive bean (Phaseolus vulgaris L., 'Nerina') and petunia (Petunia $\times$ hybrida L., 'White Cascade') were used in the experiment presented. Plants were cultivated and exposed in $1.5 \mathrm{~L}$ pots with similar soil volume and slowly released fertilizer, which was sufficient for the whole experiment period. Fourweek old bean, six-week old petunia and eight-week old tobacco were transported to the exposure sites. The sites were chosen on the basis of previous air pollution monitoring. One site was located in the city of Poznan in the Botanical Garden, and the second one about $80 \mathrm{~km}$ North-East of the city, in a forest area. Both sites were equipped in continuous monitoring of air pollution and meteorological parameters conducted by the Provincial Environmental Agency in Poznań. The period of exposure was connected with plants physiological functions and symptoms of senescence; hence tobacco was exposed for seven week, bean for six weeks and petunia for five weeks. Every week three plants of each species/cultivar were analyzed in terms of the chlorophyll content in fresh and dry matter.

\subsection{Chlorophyll content measurements}

The chlorophyll content $a+b, a$ and $b$ in fresh and dry matter was investigated. The chlorophyll $a+b, a$ and $b$ content in fresh matter was measured using the dimethyl sulfoxide extraction method [7]. Afterwards, chlorophyll in dry matter was calculated on the basis of the results of the fresh matter and dry mass content.

\subsection{Statistical analysis}

For each plant species a separate PCA analysis was conducted, making it possible to visualize the impact of variables, and subsequently the chlorophyll content $a+b, a$ and $b$ in fresh and dry matter, chlorophyll $b / a$ ratio, AOT40, 
$\mathrm{NO}_{\mathrm{X}}$, solar radiation, air temperature and mean ozone concentration, in principal components space. The empirical results of the chlorophyll content in dry matter for the particular plant species were analyzed using canonical variate analysis [9]. This method, as in the case of PCA, consists in the transformation of the original set of variables into a set of new variables, which carry similar information, but are distributed in a multivariate Euclidean space. In this case, canonical variate analysis is based on the matrix of the day of experiment effects of the chlorophyll content in dry matter. The elements of this matrix include the differences between the mean values of individual chlorophyll contents for the days of experiment considered and object means over all days [9]. Due to the specific experimental conditions PCA was performed for these species. While a comparison between the plant species results was made only for the first 5 weeks using canonical variate analysis.

\section{RESULTS AND DISCUSSION}

Results of PCA revealed that the relations between the chlorophyll contents and the environmental factors in various plant species exposed to tropospheric ozone were various. However, in all cases mean ozone concentrations were positively correlated to solar radiation and air temperature (Fig. 1). These relations are obvious due to ozone creation in favourable meteorological conditions, such as high solar radiation and temperature [1], because ozone is secondary air pollutant created during photochemical reactions.

There is no clear relation between chlorophyll contents in tobacco Bel W3. Small relations of mean ozone concentrations and solar radiation to all forms of chlorophyll were noted in this cultivar. This is also valid for tobacco Bel B and bean. While, in the case of petunia, very high relation of mean tropospheric ozone concentrations to chlorophyll content in dry matter was found. Solar radiation in this plant species was also highly related to the chlorophyll content in dry mass, while air temperature was positively related to dry and fresh chlorophyll contents of all forms. Negative relations between nitrogen oxides and chlorophyll contents were noted in both tobacco cultivars all forms of chlorophyll and petunia plant for chlorophyll in dry matter contents (Fig 1). The chlorophyll $b / a$ ratio was positively related to mean ozone concentrations in ozone-sensitive cultivars of all plant species, excluding ozone-resistant tobacco (Fig. 1). 
PRINCIPAL COMPONENT ANALYSIS OF CHLOROPHYLL CONTENT IN TOBACCO, 9 BEAN AND PETUNIA PLANTS EXPOSED TO DIFFERENT TROPOSPHERIC OZONE CONCENTRATIONS

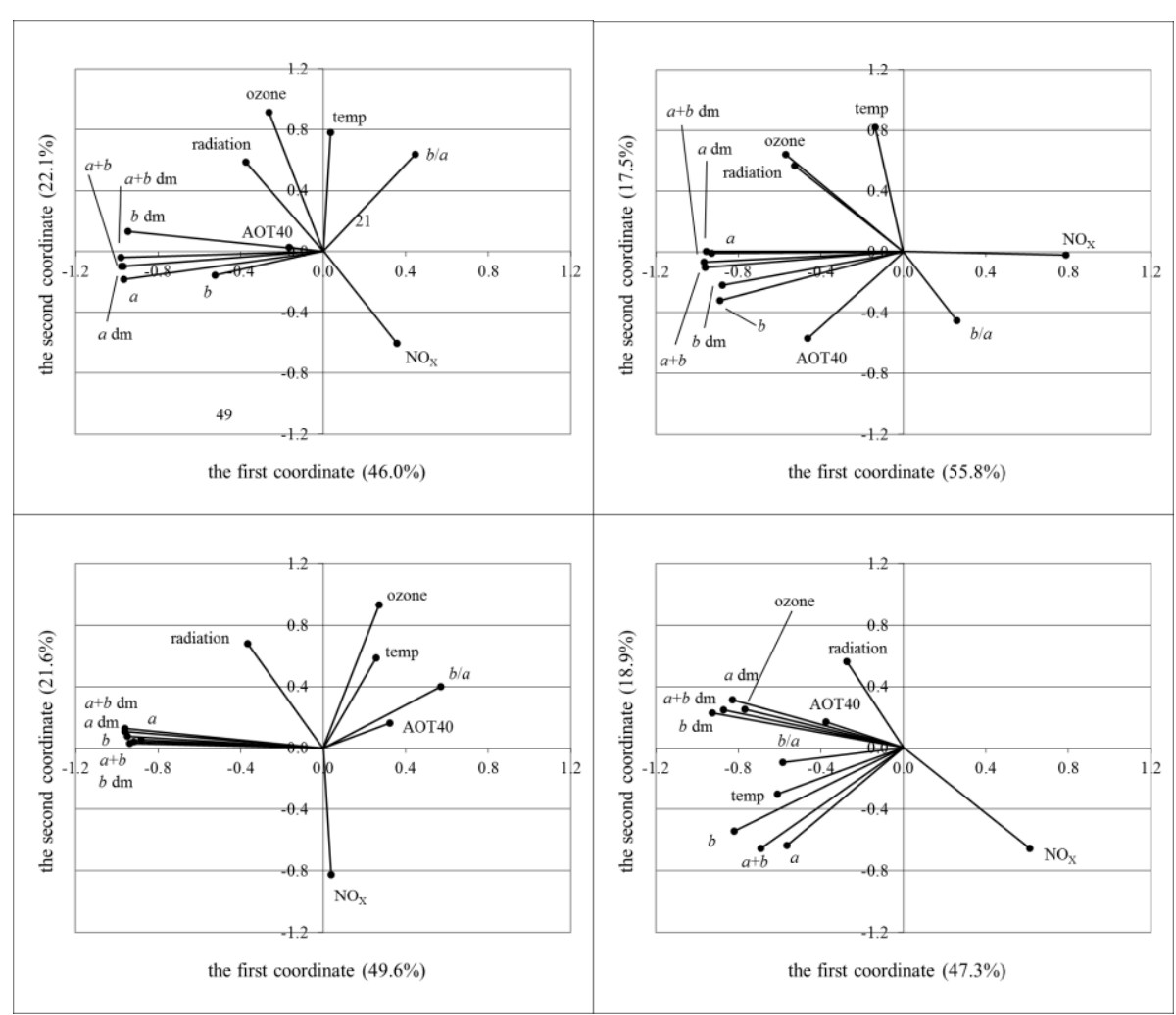

Fig. 1. Principal Components Analysis of chlorophyll contents, air pollution and meteorological parameters for 'Bel W3' and 'Bel B' tobacco cultivar, bean and petunia ( $a+b, a, b$ - chlorophyll $a+b, a$ and $b$; dm - dry mass;

temp - temperature)

A comparison between the chlorophyll contents in the selected plant species in certain observation days was presented graphically using canonical variate analysis. For these analyses only the chlorophyll content in dry mass was chosen due to better relation to ozone concentrations and higher variability. Chlorophyll $a+b$ highly varied the level of chlorophylls throughout the entire experiment period in all the plant species, while the lowest effect of chlorophyll $b$ was observed, excluding petunia (Fig. 2). 


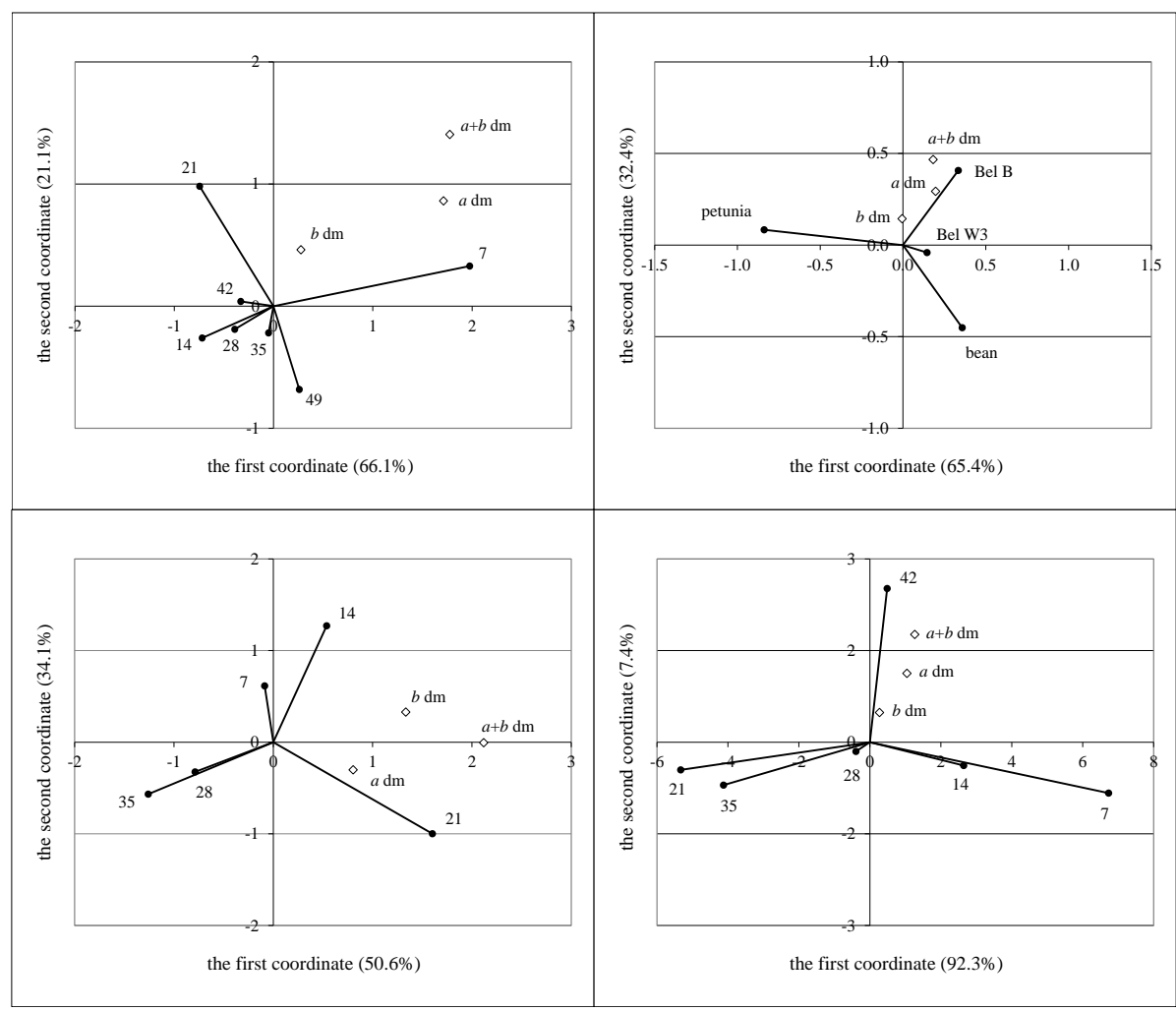

Fig. 2. Position of the day of the experiment (in relation to the chlorophyll content) in the first two canonical variates and the spacing of the chlorophyll contents in the dual space for, tobacco Bel W3 and Bel B, bean and petunia ( $a+b, a, b$ - chlorophyll $a+b, a$ and $b ;$ dm - dry mass)

Chlorophyll $a$ was found as more sensitive, hence higher losses could be noted [6]. This was also valid for our results, where chlorophyll $a$ content revealed higher variability than $b$. The highest level of all forms of chlorophyll in ozonesensitive tobacco leaves were noted on the $7^{\text {th }}$ day of the experiment, while the lowest after $14^{\text {th }}$ day. The lowest differences between chlorophyll contents were observed in the $28^{\text {th }}, 35^{\text {th }}$ and $42^{\text {nd }}$ day of the experiment (Tab. 1, Fig. 2). The chlorophyll content measurements were previously found as a parameter, which can indicate the negative ozone effect on plants [13]. It was found that an increase of visible damage caused by ozone was previously closely related to decrease of the chlorophyll content. Some plant species revealed a decrease of chlorophyll together with a tropospheric ozone increase [3, 12]. However, an increase of the chlorophyll content was noted in ozone-sensitive cultivar as a 
PRINCIPAL COMPONENT ANALYSIS OF CHLOROPHYLL CONTENT IN TOBACCO, 11 BEAN AND PETUNIA PLANTS EXPOSED TO DIFFERENT TROPOSPHERIC OZONE

CONCENTRATIONS

plant response to the decrease in the assimilation leaf area due to necrosis occurrence [16].

In the case of the chlorophyll content in the ozone-resistant tobacco cultivar the highest levels were noted again on the $7^{\text {th }}$ day of the experiment, and the lowest on the $42^{\text {nd }}$ (excluding chlorophyll $b$ ). Very low levels of chlorophyll $a+b$ and $b$ were recorded on the $28^{\text {th }}$ and $49^{\text {th }}$ day (Tab. 1), hence very close position of chlorophyll contents on these two dates was found (Fig. 2). Overall, in this tobacco cultivar we could observe relatively high levels of all chlorophyll forms in the first three weeks, excluding chlorophyll $b$ on the $14^{\text {th }}$ day (Tab. 2).

Similarly, as for the above plant species the highest level of chlorophylls were recorded on $7^{\text {th }}$ day of the experiment in bean leaves. However, the high levels were also noted after 14 and 42 days of exposure, but a different relation of chlorophyll $a+b$ to $a$ was noted (Tab. 1), hence a separate position of this day value was noted (Fig. 2). The lowest levels of the chlorophyll contents were found after 21 and 35 days of the experiment (Tab. 1), hence a very close position on the graph could be observed (Fig. 2).

Table 1. Evaluation of the mean value of the chlorophyll content in dry mass for the day of the experiment in comparison to the mean value of all the experimental days (results for tobacco Bel W3 and Bel B, bean and petunia plants).

\begin{tabular}{|c|c|c|c|c|c|c|}
\hline \multirow{2}{*}{$\begin{array}{c}\text { Day of } \\
\text { experiment }\end{array}$} & \multicolumn{3}{|c|}{ Tobacco Bel W3 } & \multicolumn{3}{|c|}{ Tobacco Bel B } \\
\hline & $a+b \mathrm{dm}$ & $a \mathrm{dm}$ & $b \mathrm{dm}$ & $a+b \mathrm{dm}$ & $a \mathrm{dm}$ & $b \mathrm{dm}$ \\
\hline 7 & $7.94 * *$ & $7.32 * *$ & $1.39 * *$ & $3.12 * *$ & $3.80 * *$ & 0.06 \\
\hline 14 & $-3.32 * *$ & $-2.87 * *$ & $-0.62 *$ & 1.22 & -0.87 & $1.18 * *$ \\
\hline 21 & 0.03 & -0.75 & 0.55 & $2.00 * *$ & $1.47 * *$ & 0.34 \\
\hline 28 & -1.93 & -1.65 & -0.38 & $-2.34 * *$ & $-1.17 *$ & $-0.88 * *$ \\
\hline 35 & -0.86 & -0.46 & -0.19 & 1.01 & $1.73 * *$ & -0.15 \\
\hline 42 & -0.79 & -1.38 & -0.31 & $-2.90 * *$ & $-4.01 * *$ & 0.20 \\
\hline 49 & -1.07 & -0.20 & -0.44 & $-2.10 * *$ & -0.96 & $-0.76^{* *}$ \\
\hline \multirow{2}{*}{$\begin{array}{c}\text { Day of } \\
\text { experiment }\end{array}$} & \multicolumn{3}{|c|}{ Bean } & \multicolumn{3}{|c|}{ Petunia } \\
\hline & $a+b \mathrm{dm}$ & $a \mathrm{dm}$ & $b \mathrm{dm}$ & $a+b \mathrm{dm}$ & $a \mathrm{dm}$ & $b \mathrm{dm}$ \\
\hline 7 & $6.98 * *$ & $6.10 * *$ & $1.45 * *$ & -1.29 & -0.29 & -0.56 \\
\hline 14 & $2.91 * *$ & $2.37 * *$ & $0.53^{*}$ & 1.72 & 1.34 & 0.21 \\
\hline 21 & $-7.46^{* *}$ & $-6.09 * *$ & $-1.69 * *$ & $3.35 * *$ & $1.79 * *$ & $1.57 * *$ \\
\hline 28 & -0.93 & -0.61 & -0.17 & -0.89 & -0.89 & -0.32 \\
\hline 35 & $-6.54 * *$ & $-5.12 * *$ & $-1.47 * *$ & $-2.89 * *$ & $-1.95 * *$ & $-0.90 *$ \\
\hline 42 & $5.05 * *$ & $3.35 * *$ & $1.35 * *$ & - & - & - \\
\hline
\end{tabular}

$*^{*} \alpha \leq 0.01 ;{ }^{*} \alpha \leq 0.05 ; a+b, a, b-$ chlorophyll $a+b, a$ and $b ; \mathrm{dm}$ - dry mass 
Table 2. Evaluation of the mean value of the chlorophyll content in dry mass for the plant species in comparison to the mean value of all the plant species

\begin{tabular}{|l|c|c|c|}
\hline \multicolumn{1}{|c|}{ Plant species } & $a+b \mathrm{dm}$ & $a \mathrm{dm}$ & $b \mathrm{dm}$ \\
\hline Tobacco Bel W3 & -0.09 & -0.07 & -0.09 \\
\hline Tobacco Bel B & $2.55^{* *}$ & $1.90^{* *}$ & $0.58^{* *}$ \\
\hline Bean & -1.34 & -0.46 & $-0.64^{* *}$ \\
\hline Petunia & -1.12 & $-1.38^{*}$ & 0.16 \\
\hline
\end{tabular}

${ }^{*} \alpha \leq 0.01 ;{ }^{*} \alpha \leq 0.05 ; a+b, a, b-$ chlorophyll $a+b, a$ and $b ; \mathrm{dm}$ - dry mass

In spite of the response of the other plants the highest level of chlorophyll contents in petunia leaves were noted after the $14^{\text {th }}$ and $21^{\text {st }}$ day of the experiment, and the lowest were recorded at the end of the experiment with this plant species. Very low levels of the chlorophyll $a$ content were observed in samples collected after the $7^{\text {th }}$ day in comparison to the other days of the experiment (Tab. 1, Fig. 2).

A comparison between the chlorophyll contents in certain plant species revealed highest levels in ozone-resistant tobacco cultivar. Bean and petunia plants revealed low and similar levels of chlorophyll $a+b$ and $a$ contents. Moreover, petunia was characterized by higher levels of the chlorophyll $b$ content in comparison to bean and tobacco Bel W3 (Tab. 2). Hence, this species revealed different a position on the graph (Fig. 3). The chlorophyll contents in Bel W3 leaves were found as the most average of all the four plant species (Tab. 2).

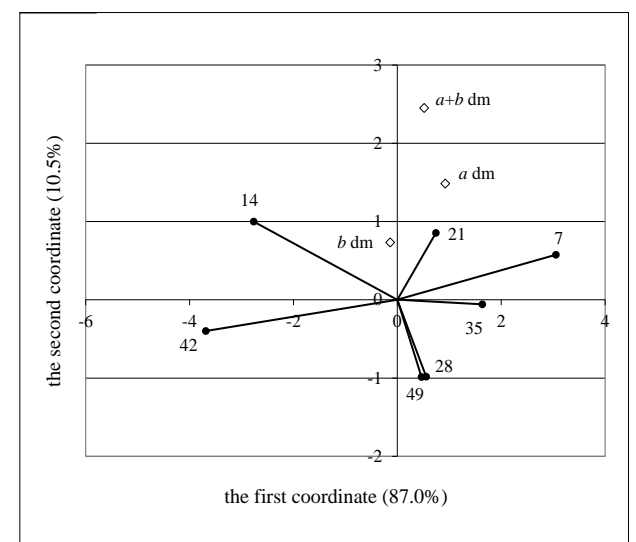

Fig. 3. Position of the plant species (in relation to the chlorophyll content) in the first two canonical varieties and the spacing of the chlorophyll contents in the dual space $(a+b, a$, $b$ - chlorophyll $a+b, a$ and $b$; dm - dry mass)

A high chlorophyll reduction of the photosynthesis process by ozone can occur with or without visible damage [14]. It was also previously found, that a higher ozone concentration can cause a higher chlorophyll reduction, and this fact can 
PRINCIPAL COMPONENT ANALYSIS OF CHLOROPHYLL CONTENT IN TOBACCO, 13 BEAN AND PETUNIA PLANTS EXPOSED TO DIFFERENT TROPOSPHERIC OZONE

CONCENTRATIONS

be used for assessing the phytotoxic effect of ozone on plants [13]. However, considering our results it seems that the chlorophyll content is changing during plant development and the cumulative ozone effect during the growing season.

The response of every plant species was different. Moreover, probably due to different meteorological conditions in certain growing seasons, various patterns of plant responses may be observed.

\section{CONCLUSIONS}

The response of the plants to tropospheric ozone varied between the tested plant species. Moreover, changes of the chlorophyll content during the growing season were noted, due to changes of physiological plant phases, as well as due to the cumulative ozone effect. However, some similarities were noted. Positive relations of all chlorophyll forms to the cumulative ozone concentration (AOT 40 ) were found for all the plant species that were examined. The chlorophyll $b / a$ ratio revealed the opposite position to the ozone concentration only in ozoneresistant tobacco cultivar. In all the plant species the highest average chlorophyll content was noted after the $7^{\text {th }}$ day of the experiment. Afterwards, the plants usually revealed various responses. Ozone-sensitive tobacco revealed a decrease of the chlorophyll content, and after a few weeks of decline again an increase was observed. Probably, due to the accommodation for the stress factor. While during the first three weeks low levels of chlorophyll contents were noted in ozone-resistant tobacco, and the lowest levels were observed at the end of the experiment due to low values for $a+b$ and $\mathrm{b}$ chlorophyll. Petunia revealed a slow decrease of the chlorophyll content and the lowest values at the end of the experiment. A comparison between the plant species revealed the highest level of chlorophyll contents in ozone-resistant tobacco.

\section{ACKNOWLEDGEMENTS}

The authors wish to acknowledge the support of project grant no. N N305 042636 from the Ministry of Science and Higher Education in the publication of this work. 


\section{REFERENCES}

1. Barret L.A., Bunce N.J., Gillespie T.J.: Estimation of tropospheric ozone production using concentrations of hydrocarbons and $N O_{x}$, and a comprehensive hydrocarbons reactivity parameter. Journal of Photochemistry and Photobiology A, 113, (1998) 1-8.

2. Borowiak K., Drzewiecka K., Zbierska J., Goliński P., Malicka M., Andrzejewska B.: Effect of tropospheric ozone on two white clover (Trifolium repens L. cv. 'Regal') clones with different ozone sensitivity exposed at rural area of Wielkopolska Region, Archives of Environmental Protection, 37, (2011a) 13-24.

3. Borowiak K., Jusik S,. Zbierska J.: Canonical Correspondence Analysis (CCA) as a tool for the interpretation of bioindication plants response to ambient air pollution, Fresenius Environmental Bulletin, 20(9), (2011b) 2264-2270.

4. Della Torre G., Ferranti F., Lupattelli M., Pocceschi N., Figoli A., Nali C., Lorenzini G.: Effects of ozone on morpho-anatomy and physiology of Hedera helix, Chemosphere 36, (1998) 651-656.

5. Fowler D.: Ground-level ozone in the 21st century: future trends, impacts and policy implications. London, the Royal Society 2008.

6. Greszta J., Gruszka A., Kowalkowska M.: Wplyw imisji na ekosystem. Katowice, Wydawnictwo Naukowe Śląsk 2002.

7. Hiscox J.D., Israelstam G.F.: A method for the extraction of chlorophyll from leaf tissue without maceration. Canadian Journal of Botany, 57, (1978) 1332-1334.

8. Laurence J.A., Amundson R.G., Friend A.L., Pell E.J., Temple P.J.: Allocation of carbon in plants under stress: An analysis of the ROPIS experiments. Journal of Environmental Quality, 23, (1994) 412-417.

9. Lejeune M, Caliński T.: Canonical analysis applied to multivariate analysis of variance. Journal of Multivariate Analysis, 72, (2000) 100-119.

10. Long S.P., Naidu S.L.: Effects of oxidants at the biochemical, cell and physiological level, with particular reference to ozone, in: Air pollution and plant life, eds. J.N.B. Bell, M. Treshow, Chichester, John Wiley and Sons 2004, 69-89.

11. Morgan P.B., Ainsworth E.A., Long S.P.: How does elevated ozone impact soybean? A meta-analysis of photosynthesis, growth and yield. Plan, Cell and Environment, 26, (2003) 1317-1328.

12. Raskin I.: Role of salicylic acid in plants. Annual Review of Plant Physiology and Plant Molecular Biology, 43, (1992) 439-463. 
PRINCIPAL COMPONENT ANALYSIS OF CHLOROPHYLL CONTENT IN TOBACCO, 15 BEAN AND PETUNIA PLANTS EXPOSED TO DIFFERENT TROPOSPHERIC OZONE CONCENTRATIONS

13. Saitanis, C.J., Riga-Karandinos, A.N., Karandinos, M.G.: Effects of ozone on chlorophyll and quantum yield of tobacco (Nicotiana tabacum l.) varieties. Chemosphere 42, (2001) 945-953.

14. Scebba F., Soldatini G., Ranieri A.: Ozone differentially affects physiological and biochemical response of two clover species; Trifolium repens and Trifolium pratense. Environmental Pollution, 123, (2003) 209216.

15. Welfare, K., Flowers, T.J., Taylor, G. Yeo, A.R.: Additive and antagonistic effects of ozone and salinity on the growth, ion content and gas exchange of five varieties of rice Oryza sativa L. Environmental Pollution, 92, (1996) 257-266.

16. Zbierska J., Borowiak K.: Wybrane reakcje zewnętrzne $i$ wewnętrzne tytoniu szlachetnego na obecność ozonu troposferycznego. Zeszyty Naukowe AR Kraków - seria Inżynieria Środowiska, 25, (2004) 377-388.

\author{
ANALIZA SKŁADOWYCH GŁÓWNYCH ZAWARTOŚCI CHLOROFILU \\ W ROŚLINACH TYTONIU, FASOLI I PETUNII EKSPONOWANYCH NA \\ STANOWISKACH O RÓŻNYCH STĘŻENIACH OZONU TROPOSFERYCZNEGO
}

Streszczenie

W zaprezentowanych badaniach wykorzystano trzy gatunki roślin - tytoń szlachetny (odmiana wrażliwa oraz odporna na ozon), odmiany wrażliwe petunii oraz fasoli. Rośliny eksponowano na dwóch stanowiskach różniących się stężeniem ozonu troposferycznego w sezonie wegetacyjnym 2009 roku. Co tydzień wykonywano pomiary zawartości chlorofilu wybranych roślin. Powiązanie kumulatywnych stężeń ozonu względem zawartości chlorofilu oraz wybranych parametrów meteorologicznych wykonano za pomocą analizy składowych głównych, natomiast do porównania reakcji roślin $\mathrm{w}$ poszczególnych dniach ekspozycji wykorzystano wielowymiarową analizę wariancji. Badania wykazały zróżnicowanie pomiędzy gatunkami w reakcji na obecność ozonu troposferycznego. Zauważyć jednak można pewne tendencje. Stwierdzono pozytywną zależność pomiędzy zawartością wszystkich form chlorofilu dla wszystkich badanych gatunków i kumulatywnym stężeniem ozonu (AOT 40). Wskaźnik chlorofilu b/a wykazał odwrotną tendencję względem AOT 40 jedynie dla odmiany odpornej na ozon tytoniu. Wszystkie gatunki wykazały najwyższy poziom chlorofilu w 7 dniu ekspozycji, a w następnych dniach odpowiedź roślin była zróżnicowana. Odmiana wrażliwa tytoniu wykazała zmniejszenie zawartości chlorofilu, a po kilku tygodniach ponownie wzrost, co może sugerować adaptację do warunków stresowych. Odmiana odporna tytoniu wykazała relatywnie wysokie poziomy chlorofilu w ciagu pierwszych trzy tygodni 
ekspozycji. Petunia wykazała stopniowy spadek zawartości chlorofilu w ciagu trwania eksperymentu. Porównanie odpowiedzi wybranych gatunków wykazało najwyższe poziomy chlorofilu u odmiany odpornej tytoniu.

Słowa kluczowe: ozon troposferyczny, wrażliwość, odporność, chlorofil

Editor received the manuscript: $\quad$ 18.07.2013 